\title{
NURGAYAZ GARIFYANOV: A PROMINENT EXPERIMENTAL PHYSICIST OF THE CENTURY
}

\author{
Anis Foatovich Galimyanov, \\ Kazan Federal University, \\ 18 Kremlyovskaya Str., Kazan, 420008, Russian Federation, \\ anis_59@mail.ru.
}

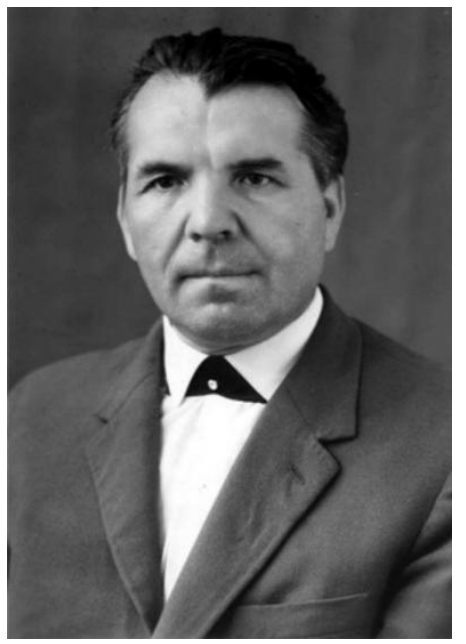

Nurgayaz Salikhovich Garifyanov (1920-1970) - a physicist, Doctor of Physical and Mathematical Sciences (1965), Professor (1970), Honored Scientist of the TASSR (1970), a veteran of the Great Patriotic War; he worked at the Physical-Technical Institute of the Kazan Scientific Center of the USSR Academy of Sciences from 1952 to 1970 and headed the laboratory at the mentioned institute from 1968.

$\mathrm{He}$ is the author of more than 100 scientific works; more than ten $\mathrm{PhD}$ theses were completed under his supervision. His main research works are devoted to electron paramagnetic resonance (EPR) in complex fluids and glass. For the first time in the world, he discovered the spin orientation of the Fe57 nuclei and developed an effective method for distinguishing properties and structures of complex compounds without breaking them down to their pure steady state. He examined about 200 compounds, most of which were discovered for the first time.
Нургаяз Салихжан улы Гарифжанов (1920-1970) физик, физика-математика фәннәре докторы (1965), профессор (1970), ТАССРның атказанган фән эшлеклесе (1970). Бөек Ватан сугышы ветераны. 1952-1970 нче елларда СССР Фәннәр Академиясе Казан филиалының Физика-техника институтында эшли. 1968 нче елдан шул ук институтта лаборатория мөдире.

100 дән артык фәнни хезмәт авторы, аның житәкчелегендә уннан артык кандидатлык диссертациясе якланган. Төп фәнни хезмәтләре комплекслы эремәләрдә һәм пыялаларда электрон парамагнит резонансына багышланган. Дөньяда беренче тапкыр $\mathrm{Fe}^{57}$ төшенең спинын тапкан һәм эремәләрдәге химик комплексларның, аларны чиста хәлдә бүлеп чыгармыйча гына, составын һәм төзелешен табуның эффектив методын эшләгән. Бу метод ярдәмендә ике йөзгә якын комплексны тикшергән, аларның күбесе беренче тапкыр табылган.
Нургаяз Салихович Гарифьянов (1920-1970) - физик, доктор физико-математических наук (1965), профессор (1970). Заслуженный деятель науки ТАССР (1970). Ветеран Великой Отечественной войны. Работал в 19521970 гг. в Физико-техническом институте Казанского филиала Академии Наук СССР. Заведующий лабораторией того же института с 1968 г.

Автор более 100 научных работ, под его руководством было защищено более 10 кандидатских диссертаций. Основные научные работы посвящены электронному парамагнитному резонансу в комплексных растворах и стеклах. Впервые определил спин ядра $\mathrm{Fe} 57$ и разработал эффективный метод установления состава и строения химических комплексов в растворах без выделения их в чистом виде. С помощью этого метода исследовал свыше двухсот комплексов, многие из которых были получены впервые. 
May 15, 2020 marked the 100th anniversary of the prominent physicist Nurgayaz Salikhovich Garifyanov. The biography of my fellow villager is as vibrant, fruitful, and honourable as the biography of the Tatar people...

There were three brick houses in our village. They say that one of them, the one with a very beautiful exterior, belonged to the Garifyanovs. Salikh Garifyanov was a wealthy householder. The future famous scientist Nurgayaz Garifyanov was born into the family of Salikh and Galima Garifyanov from Chutayevo village, the Tsipyinsky district (now the Baltasinsky district) on May 15, 1920. In the 1920s-1930s, leaving all his property behind, Salikh, along with his family, moved from the village to Malmyzh, where he got a job on a construction site. It may not have been easy for him to leave his home village and everything he had earned, but he did it to save his family. The Bulatovs, their fellow villager's family, (the future Hero of the Soviet Union Gabdulla (Vasily) Bulatov) were labelled "kulaks" and were exiled to Siberia. The same fate befell the family of Salikh.

Nurgayaz was 8 years old when they moved to Malmyzh. He joined the Malmyzhskaya Tatar Primary School the same year and graduated from high school in 1938. The keystone of his childhood, like of all the children born after the October Revolution and brought up in the Soviet country, was proper education and constant gain of knowledge. After high school, he worked at the Malmyzh district radio station as a radio operator. It was probably then when the future physicist began to develop his skills, as he had to deal with radio parts and devices that were quite advanced for that time. His desire to understand the essence of radiophysics led him to Kazan State University. Nurgayaz Garifyanov entered the faculty of physics and mathematics of Kazan State University in 1939. The Great Patriotic War, which began in 1941, changed his plans. He was drafted into the Red Army after his second year at university. Although he was initially sent to the infantry school in the Arkhangelsk region, he was later transferred to a reserve military brigade in the Kirov region. Considering that he was a physicist by education, Garifyanov was to be trained as a junior radio commander. He was later transferred to the Murom School of Military Communications, which he left in 1943, and was sent to the South Front in Melitopol as a junior lieutenant. He joined the war as a commander of a radio platoon of the 4th Guards Division of the Order of the Red Banner in the 5th Company of the 11th Infantry Regiment. He participated in the liberation of Ukraine, Moldova, Romania, Hungary, Bulgaria, Yugoslavia, and Austria. He was known as a brave, strongwilled, caring, and demanding commander during the war. Nurgayaz Garifyanov was lightly wounded in the fierce battles of the Dniester defence, It was a month before the Great Victory, that he got severe injuries during the intense battles of the liberation of Budapest.

Nurgayaz often recounted one cathartic experience that he came upon during the war years. He had a quite heavy pocket watch and always carried it in the left pocket of his soldier blouse. This very watch saved him from the Nazi bullet that was supposed to bring him to his death. However, this wound would bother him throughout his life. After six months of treatment at the hospital, he was appointed a commander of the 68th Guards Division of the Order of the Red Banner in a separate training radio platoon in May, 1945, where he was engaged in training radio operators. For the courage displayed in the Great Patriotic War, N. Garifyanov was awarded the Order of the Red Star and the medal "For the Capture of Budapest". Being a disabled war veteran, he was discharged from the Red Army on March 20, 1946.

After the war, Nurgayaz Garifyanov continued his studies and, upon his graduation from Kazan State University in 1949, entered the Graduate School in the Department of Physics led by Boris Kozyrev, a prominent scientist at the PhysicalTechnical Institute of the Kazan Scientific Center, the USSR Academy of Sciences. Nurgayaz Garifyanov was his first student and rendered irreplaceable support in the creation of the scientific school of EPR (electron paramagnetic resonance) at the Kazan Physical-Technical Institute.

The scientific path of Nurgayaz Garifyanov was not simple. His research supervisor Boris Kozyrev encouraged him to study paramagnetic resonance in rare element compounds. The first steps of N. Garifyanov's scientific work were the years when he sought his own style and trend in science.

Semen Altshuler, a well-known Kazan physicist, also took interest in his research. He and B. Kozyrev would go to Garifyanov's laboratory to work on this subject. At first, the work was difficult and attempts to catch paramagnetic resonance signals failed. Then, Nurgayaz Garifyanov changed the generator circuits and replaced the lamps. He worked late at the Institute, even spent many nights there. Finally, the stubborn process 
yielded certain results. N. Garifyanov published the results of his research in JETP (Journal of Experimental and Theoretical Physics), one of the most prestigious and oldest journals in physics, and defended his $\mathrm{PhD}$ thesis on "Paramagnetic Absorption in Compounds of Certain Lanthanide Elements" in 1953.

After successfully completing his graduate studies, in the recommendation letter, written by the head of the Kazan Physical-Technical Institute H. Mushtari and his research supervisor B. Kozyrev, he was characterized as follows: "Given that comrade N. Garifyanov is a highly qualified researcher and competent experimenter with unique qualities, he should be included in the list of performers of experiments on a very important topic, assigned to the Institute by the Council of Ministers of the USSR, which will undoubtedly facilitate the effective realization of this topic. The Physical-Technical Institute considers it necessary to have him in the Department of Physics".

In the mid-1940s, the discovery of the electron paramagnetic resonance phenomenon, made by Kazan experimental physicist Yevgeny Zavoysky, was equated, in terms of its significance, with Lobachevsky's development of nonlinear geometry and Mendeleev's compilation of the periodic table of chemical elements. High demands were set for the researchers involved in this field of study. $\mathrm{N}$. Garifyanov would work at this institute exploring magnetic resonance spectroscopy till the end of his life.

His first disciple, Doctor of Physical and Mathematical Sciences, Academician of the Academy of Sciences of the Republic of Tatarstan, Akhat Ilyasov writes:

"At first, it seemed odd to me that such a masculine, war-torn man laughed and rejoiced like a child when he was confronted with something unusual. If we succeeded in doing something, he would shout out to his trustworthy colleagues: "Now, look what has happened!". He would always share his ideas and discoveries with everyone.

Our communication later developed into a strong friendship. Since then, he became my teacher and mentor not only in science but also in life. Later, in 1968, I had a serious car accident and miraculously survived. He visited me every day at the hospital. I have always believed and still do that it was Nurgayaz Garifyanov who saved me from deep depression and brought me back to life".

N. Garifyanov established himself as a worldrenowned experimenter in the field of magnetic resonance spectroscopy. The research on paramagnetic resonance has proved very productive for nuclear physics. It is used in the study of the most complex chemical reactions, the structure of solid and liquid substances. N. Garifyanov presented his doctoral thesis "Experimental Research on Resonance Paramagnetic Relaxation" in 1965. In 1968, Nurgayaz Garifyanov was appointed head of the Electron Paramagnetic Resonance (EPR) Laboratory of the Kazan Physical-Technical Institute

Professor Garifyanov's scientific heritage includes more than 100 works. Many of his students in Voronezh, Baku, Saratov, and many other cities would already be leading their own research groups. N. Garifyanov conducted his scientific activities in several areas. The most extensive and significant among them was the study of transition metal compounds and rare earth elements. The main achievement of Nurgayaz Garifyanov was the use of EPR as an analytical method for recognizing the structure of elements. Using magnetic or nuclear resonance, it is possible to recognize a particular element's structure, its geometry, and the location of atoms in a molecule. These discoveries brought him worldwide fame.

In the review of Garifyanov's doctoral thesis, E. Zavoysky wrote: “... We are well aware that N. Garifyanov is a talented and proactive experimental physicist. He makes the equipment for most of his experiments by himself and comes up with unique and original ways of performing them. The scientist was the first to study low-temperature glasses. He discovered many new properties of EPR, the importance of which is immeasurable... The vast majority of his works are devoted to the study of EPR in free radicals and alkali metals. N. Garifyanov demonstrated his scientific creativity, intelligence, and ability to find the shortest path to reach the goal. The presented studies characterize him as a talented researcher who has found his scientific trend in magnetic spectroscopy and educated many fellow researchers".

Today, the research supervisor of the Kazan Physical-Technical Institute K. Salikhov recalls what his colleagues used to say when he was working in Akademgorodok ("the Academic Town") back in the 1960s. At that time, American scientists studied our discoveries of the EPR thoroughly, re-examining every breakthrough and findings made by our scientists. Only Garifyanov's discoveries were accepted without such scrutiny.

What does EPR mean for our daily life, and how can we benefit from it? This question may arise in many people. According to the interview 
with "Business Online", given by A. Ilyasov, N. Garifyanov's former student, the use of EPR in practice has brought significant results. Garifyanov invented an express-test method used to determine the amount of vanadium in oil for the oil and oil refining industries. This was back in the 1960s, during the space age. All of the oil-based rocket fuels contained traces of vanadium. If the amount of this metal exceeds one-tenth of a per cent, vanadium corrosion may occur in turbines. Of course, chemists would have their own suggestions. However, Nurgayaz Garifyanov suggested the method that could bring results in a second. Corrosion can destroy turbine blades and the walls of the turbine, so this solution was of extreme importance. However, due to the disunity between the fundamental and applied sciences in this country, the research results were not implemented. Shortly after, an advertisement for a small-sized EPR spectrometer that determined the amount of vanadium in products was published in an American magazine.

A similar situation occurred with car tires. During those years, the first Secretary of the Tatarstan Regional Committee Fikret Tabeev set the following task to the researchers of the PhysicalTechnical Institute: "Why can foreign tires withstand hundreds of thousands of kilometres, but for some reason, our tires can survive only 30-40 thousand kilometres?" Scientist Garifyanov took initiative for bringing solutions to this issue. In the process of tire manufacturing, tires are usually filled with soot during the vulcanization of rubber. Nurgayaz Garifyanov determined the optimal grade for the filler using EPR. However, this achievement did not go beyond a laboratory experiment either. According to A. Ilyasov, Garifyanov went on a business trip to tire manufacturing facilities in Barnaul and Nizhnekamsk as a young specialist. Heads of these facilities would say: "Of course, you have come up with this great idea. But where are we supposed to get your "right" soot from? We just fill them with whatever they give us". Even though soot was produced at the same facilities, production plans always came first at that time.

Fortunately, there were many cases with positive outcomes. To hold broken bones in the proper position, surgeons install metal rods for internal fixation. However, doctors could not tell exactly when they would be able to remove them. At the time, the Kazan Institute of Traumatology proposed a method for determining the timeline of bone regrowth based on EPR. This method was invented by Garifyanov, and Kazan doctors successfully used it in their practice. Moreover, new methods for speeding up the diagnosis of tumors using tomography were discovered by Garifyanov and his students, and have been successfully applied in practice.

The great scientist N. Garifyanov passed away two months before his 50th Jubilee.

The study of paramagnetic compounds of transition elements and lanthanides brought the scientist worldwide fame. These research activities paved the way for a new trend in chemical physics: the study of the structure and properties of paramagnetic compounds without breaking them down. He made the discovery that the metal compounds could be in their unusual valence states and the idea was not initially supported by chemists. Yet, later it was widely recognized. In order to perpetuate the memory of N. Garifyanov, the Malmyzhskaya High School, where he studied, was named after him; and the Kazan City Council Executive Committee decided to name one of the streets in the Gorki residential area in Kazan after Prof. N. Garifyanov on May 11, 1971. There is also a documentary film about the scientist called "Nauka Zhit"” ("A Science of Living").

In 1970, after N. Garifyanov had passed away, the annual Garifyanov readings were organized at the initiative of academician E. Zavoysky. During one of the Garifyanov readings, the corresponding member of the USSR Academy of Sciences B. Kozyrev said the following: "This person had an exceptional gift. Everyone who was connected with him knows that he was kind, humane, and sentimental. His simplicity was extraordinary. His creative enthusiasm passed on to all his students and colleagues. Both his work and theirs was thriving. If you could say "he got burned out at work" about someone, it would be about him".

\section{References}

Eksperimenty ot Professora Garif'ianova - Made in USSR, Provereno v SSHA [Experiments from Professor Garifyanov - Made in the USSR, Tested in the USA]. BUSINESS Online: https://www.business-gazeta.ru/ article/468729. (In Russian)

Moshhyr tatar galimnore: mokalalar, istaleklar (2011) [Famous Tatar Scholars: Articles, Memoirs]. Tez.: R. Ә. Shakirkanov, A. I. Narbekov, F. R. Shakirkanov. 423 p. Kazan, Tatars. kit. nəshr., phot. bn. (In Tatar) 


\title{
НУРГАЯЗ ГАРИФЖАНОВ - ЗАМАНЫБЫЗНЫН АТАКЛЫ ФИЗИК- ЭКСПЕРИМЕНТАТОРЫ
}

\author{
Әнис Фоат улы Галимжанов, \\ Казан федераль университеты, \\ Россия, 420008, Казан ш., Кремль ур., 18 нче йорт, \\ anis_59@mail.ru.
}

Күренекле физик Нургаяз Салих улы Гарифжановның тууына 2020 нче елның 15 нче маенда 100 ел булды. Авылдашымның биографиясе татар халкы биографиясе өлгесе кебек сикәлтәле, эшлекле, мактаулы ...

Авылыбызда кирпечтән төзелгән өч йорт бар иде. Аларның берсе, бик матур архитектуралысы, Гарифжановларныкы булган дип сөйлиләр. Хәлле хужа булган Салих абый. Менә шул Салих абый белән Галимә апа гаиләсендә Чепья районы (хәзер Балтач районы) Чутай авылында 1920 нче елның 15 нче маенда булачак күренекле галим Нургаяз Салих улы Гарифжанов дөньяга килә. Салих абый 20-30 нчы елларда, барлык малын калдырып, гаиләсе белән авылдан Малмыжга күчә дә төзелешкә эшкә урнаша. Аңа барлык эшләп тапкан малын, туган авылын калдырып китү жиңел булмагандыр, әмма ул моны гаиләсен коткарып калу өчен эшли. Авылдашлары Булатовлар (булачак Советлар Союзы Герое Габдулла (Василий) Булатов) гаиләсен кулак дип, Себергә сөрәләр. Салих абый гаиләсен дә шундый язмыш көткән.

Малмыжга күчкәндә Нургаязга 8 яшь була. Ул шул ук елны Малмыж татар башлангыч мәктәбенә укырга керә, урта мәктәпне 1938 нче елда тәмамлый. Аның балачагының нигезендә Октябрь түнтәрелешеннән соң туган һәм Совет илендә тәрбияләнгән барлык балаларныкы кебек үк, белем алу, алган белемне арттыру була. Урта мәктәптән соң ул Малмыж район радиоузелына «радионадсмотрщик» булып эшкә керә. Шул вакытта ук инде анда булачак галим-физик формалаша башлагандыр, чөнки аңа чоры өчен бик катлаулы булган радио детальләре һәм жайланмалары белән эш итәргә туры килә. Радиофизиканың асылын аңларга теләү хисе аны Казан дәүләт университетына алып килә. 1939 нчы елда Нургаяз Гарифжанов Казан дәүләт университетының физикаматематика факультетына укырга керә. 1941 нче елда башланган Бөек Ватан сугышы аның язмышын үзгәртә. Нургаяз Салих улы университетның 2 нче курсыннан соң Кызыл Армия сафларына алына. Башта аны
Архангельск өлкәсендәге пехота училищесына жибәрсәләр дә, соңыннан, белеме буенча физик икәнен исәпкә алып, кече командир-радист итеп әзерләу өчен, Киров өлкәсендәге запастагы хәрби бригадага күчерәләр. Соңыннан ул Муром хәрби элемтә училищесына күчерелә һәм аны 1943 нче елда тәмамлап, кече лейтенант дәрәжәсендә Көньяк фронтка, Мелитополь шәһәренә жибәрелә. Кызыл Байрак орденлы 4 нче гвардия дивизиясенең 11 нче укчы полкы составындагы 5 ротада радиовзвод командиры булып сугышка кереп китә. Украина, Молдавия, Румыния, Венгрия, Болгария, Югославия, Австрияне азат итүдә катнаша. Сугышта ул батыр, нык ихтыярлы, кайгыртучан hәм таләпчән командир булып таныла. Днестр оборонасын өзүдәге каты сугышлар вакытында ул жиңелчә, ә Бөек Жиңүгә бер ай калганда, Будапештны азат итү өчен барган дәһшәтле сугышларда авыр яралана.

Сугыш елларында күргәннәреннән бер гыйбрәтле вакыйганы еш искә ала Нургаяз абый. Аның бик саллы кесә сәгате була һәм ул аны һәрвакыт гимнастеркасының сулъяк түш кесәсендә йөртә. Үлем алып килгән фашист пулясыннан шул сәгать саклап кала да инде аны. Ләкин бу яра аны гомере буена борчый. Госпитальдә ярты ел дәвалангач, аны 1945 нче елның маенда Кызыл Байрак орденлы 68 нче гвардия дивизиясенә, аерым уку-укыту радиовзводына командир итеп билгелиләр hә ул радистлар әзерләү белән шөгыльләнә. Бөек Ватан сугышында күрсәткән батырлыклары өчен Н.С. Гарифжанов Кызыл Йолдыз ордены, «Будапештны алган өчен» медальләре белән бүләкләнә. 1946 нчы елның 20 мартында, сугыш инвалиды буларак, ул Кызыл Армиядән демобилизацияләнә.

Сугыштан соң Нургаяз Салих улы укуын дәвам итә һәм 1949 нчы елда, Казан дәүләт университетын тәмамлаганнан соң, СССР Фәннәр академисе филиалы Казан физикатехника институтының күренекле галим Борис Михайлович Козырев житәкләгән физика секторы каршындагы аспирантурага укырга 
керә. Нургаяз Салих улы аның беренче шәкерте hәм Казан физика-техника институтында ЭПР (электрон парамагнит резонансы) фәнни мәктәбен төзегәндә алыштыргысыз терәге була.

Нургаяз Салих улының фәнни язмышы жиңел булмый. Фәнни житәкчесе Борис Михайлович Козырев аңа сирәк элементлар кушылмаларында парамагнит резонансы белән шөгыльләнергә тәкъдим итә. Н.С. Гарифжановның фәнни эшенең беренче адымнары $\mathrm{Y}^{3}$ стилен hәм фәнни

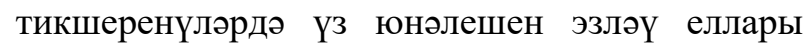
булып тора.

Аның тикшеренүләре күренекле Казан физигы Семен Альтшулерны да кызыксындыра. Алар Б.М. Козырев белән Гарифжанов эшләгән лабораториягә кереп, аларның тикшеренүләре белән танышып баралар. Башта эш авыр бара, парамагнит резонансы сигналларын тоту омтылышлары уңышсызлыкка очрый. Нургаяз Гарифжанов генератор схемаларын үзгәртә, лампаларны алыштыра. Ул институтта төнгә кадәр эшли, еш кына кунып та кала торган була. Ниһаять, киеренке эш нәтижә бирә. Н.С. Гарифжанов тикшерену нәтижәләрен физика буенча иң дәрәжәле һәм иң өлкән журналларның берсе булган ЖЭТФ (Эксперименталь һәм теоретик физика журналы) та чыгара һәм 1953 нче елда «Кайбер лантаноид элементлар кушылмаларында парамагнит йотылу» темасына кандидатлык диссертациясе яклый.

Аспирантураны уңышлы тәмамлаганнан соң аңа Казан физика-техника институты директоры X.M. Мөштәри һәм фәнни житәкчесе Б.М. Козырев биргән характеристикада: «Тикшерүче буларак иптәш Н.С. Гарифжановның югары квалификацияле һәм зур тәжрибәле экспериментатор булуын һәм аңа гына хас яхшы сыйфатларны исәпкә алып, СССР Министрлар Советы тарафыннан институтка йөкләнгән бик мөһим тема буенча эш башкаручылар исемлегенә Н.С. Гарифжановны керткәндә, һичшиксез, бу теманы сыйфатлы итеп үтәп чыгу бик нык жиңеләячәк. Физика-техника институты аны физика секторында калдыруны бик кирәк дип саный», - дип язылган.

1940 нчы еллар уртасында Казан физигыэкспериментаторы Евгений Завойский тарафыннан электрон парамагнит резонансы күренешен ачуны, әһәмияте буенча, Лобачевскийның евклид булмаган геометриясен эшләү, Менделеевның химик элементлар таблицасын төзүе белән тиңләштерәләр. Бу өлкәдә тикшерену алып баручыларга ифрат югары таләпләр куела. Н.С. Гарифжанов бу институтта магнит радиоспектроскопиясе өлкәсендә гомеренең ахырына кадәр киеренке һәм нәтижәле эшли.

Аның беренче шәкерте, физика-математика фәннәре докторы, ТР ФА академигы Әхәт Вахит улы Ильясов болай яза.

«Минем өчен баштарак шундый олпат, сугыш үткән ирнең көлүе һәм нинди дә булса гадәти булмаган нәрсә белән очрашкач бала кебек шатлануы гажәеп тоела иде. Нәрсә булса да уңышлы чыкса, ул һичшиксез коллегаларына "Юк, кара әле нәрсә килеп чыкты!” дип кычкырып әйтә иде. Ул hәрвакытта һәм барысы белән дә үзенең идеяләре, ачышлары белән бүлеште.

Аның белән аралашу соңыннан нык дуслыкка әверелде. Шул вакыттан бирле ул минем фән буенча гына түгел, ә тормышта да укытучым һәм остазым булды. Соңрак, 1968 нче елда, мин житди автомобиль катастрофасына эләктем hәм могжиза белән генә исән калдым. Ул минем янга хастаханәгә көн саен килә иде. Мин һәрчак нәкъ менә Нургаяз Салих улы мине тирән депрессиядән чыгарып, тормышка кайтарды дип санадым һәм саныйм».

Н.С. Гарифжанов магнит радиоспектроскопиясе өлкәсендә үзен дөньякүләм күренекле экспериментатор итеп күрсәтә. Парамагнит резонансы өлкәсендә тикшеренүләр төш физикасы өчен бик нәтижәле булып чыга. Ул химик реакцияләр барышының иң катлаулы сорауларын, каты һәм сыек матдәләр төзелешен өйрәнгәндә кулланыла. Н.С. Гарифжанов «Резонанс hәм парамагнетик релаксацияне тәжрибә ысулы белән тикшерү» темасына докторлык диссертациясен 1965 нче елда яклый. 1968 нче елда Нургаяз Салих улы Казан физика-техника институтының электрон парамагнит резонансы (ЭПР) лабораториясе мөдире итеп билгеләнә.

Профессор Гарифжановның фәнни мирасы 100 дән артык фәнни эшне үз эченә ала. Аның Воронеж, Баку, Саратов һәм башка шәһәрләрдәге күп санлы шәкертләренең күбесе инде Үз фәнни төркемнәре белән житәкчелек итәләр. Н.С. Гарифжанов фәнни эшчәнлеген берничә юнәлештә алып бара. Алар арасында иң күләмле, иң әһәмиятлесе - күчмә төркемнәрнең hәм сирәк элементларның комплекслы кушылмаларын өйрәнү. Нургаяз 
Салих улының биредәге иң төп казанышы ЭПРны матдә төзелешен танып белүнең аналитик методы буларак куллану. Теге яисә бу матдә ничек төзелгәнен, аның геометриясен, молекуладагы атомнар ничек урнашканын магнит яисә төш резонансы ярдәмендә белеп була. Бу тикшеренүләр аңа дөньякүләм дан китерде.

Нургаяз Салих улының докторлык диссертациясенә рецензиядә Е.К. Завойский болай яза: « ... Н.С. Гарифжановны без сәләтле hәм инициативалы физик-экспериментатор буларак яхшы беләбез. Ул күпчелек эшләрендә тәжрибәләргә жиһазларны үз кулы белән ясый, аны куюда башкаларга охшамаган, үзенчәлекле өр-яңа юлларын таба. Галим түбән температуралы пыялаларны беренче булып өйрәнә. Аның тарафыннан ЭПРның бик күп яңа юнәлешләре ачылды, аларның әһәмияте бәяләп бетергесез... Аның тарафыннан бу өлкәдә ЭПРның бик күп юнәлешләре ачылды, аларның мөһимлеге бәяләп бетергесез... Аның шактый эшләре ирекле радикалларда һәм селтеле металларда ЭПРны тикшерүгә багышланган. Биредә дә Н.С. Гарифжанов үзенең уйлап табуга сәләтен, зирәклеген, куелган максатка ирешүнең иң кыска юлын табу осталыгын күрсәтте. Тәкъдим ителгән эшләр аны бик тә сәләтле фәнни тикшеренүче, радиоспектроскопиядә үзенең фәнни юнәлешен ачучы һәм күп фәнни хезмәткәрләр тәрбияләүче итеп сыйфатлый».

Бүгенге көндә Казан физика-техника институтының фәнни житәкчесе К.М. Салихов 1960 нчы елларда Новосибирск фәнни шәһәрчегендә эшләгәндә үк коллегаларының сөйләгәннәрен искә ала. Шул вакытта Америкада безнең галимнәрең ЭПР өлкәсендәге ачышларын бик жентекләп өйрәнгәннәр һәм бездә алынган һәр яңалыкны, яңа нәтижәләрне кабат тикшереп барганнар. Бары тик Гарифжанов тапкан нәтижәләрне генә тикшермичә кабул иткәннәр.

ЭПР көндәлек тормышта нигә кирәк, аннан нинди файда булырга мөмкин? Бу сорау күпләрдә туарга мөмкин. Н.С. Гарифжановның шәкерте Ә.В. Ильясов «Бизнес-онлайн» газетасына биргән интервьюда әйткәнчә [2], гамәли өлкәләрдә ЭПР куллану сизелерлек нәтижәләргә китерә. Нефть һәм нефть эшкәртү өлкәләре өчен, Гарифжанов нефтьтә ванадий күләмен билгели торган экспресс-метод тәкъдим итә. Бу әле 1960 нчы елларда, космосны үзләштерү елларында була. Нефтьтән эшләнә торган ракета ягулыкларының барысында да ванадий була. Әгәр бу металл күләме процентның ун меңнән береннән арта икән, турбиналарда ванадий коррозиясе килеп чыгарга мөмкин. Билгеле, химикларның үз тәкъдимнәре була. Ләкин Нургаяз Салих улы мизгел эчендә эшли торган ысулны күрсәтә. Коррозия турбина калакларын һәм турбина эчен жимерергә сәләтле, шуңа күрә мондый ысул бик кирәк булган. Ләкин, илдәге фундаменталь һәм гамәли фәннәр арасындагы өзеклек аркасында, тикшеренү нәтижәләре тормышка ашмый. Озак вакыт та үтми, Америка журналарының берсендә продуктлардагы ванадий микъдарын билгели торган кечкенә габаритлы ЭПР-спектрометрга реклама чыга.

Шундый ук хәл автомобиль шиннары белән дә килеп чыга. Шул елларда Татарстан өлкә комитетының беренче секретаре Фикрәт Табеев, физика-техника институты галимнәре алдына «Чит ил шиннары йөзәр мең чакрымга түзә, ә безнекеләр ни өчен нибары 30-40 мең километрга гына чыдый?» дигән сорау куя. Бу мәсьәләне чишәргә галим Гарифжанов алына. Шиннар ясау процессында, каучук вулканизациясе вакытында, алар корым белән тутырыла. Нургаяз Салих улы, ЭПР ярдәмендә, тутыргыч өчен оптималь сортны билгели. Ләкин бу очракта да эш тәжрибәдән ары узмый. Әхәт Вахит улы сөйләгәнчә, аны, яшь белгеч сыйфатында, Барнаулдагы һәм Түбән Камадагы шин заводларына командировкага жибәрәләр. Бу заводларның директорлары: «Сез моны шәп уйлап тапкансыз, билгеле. Ләкин без сезнең "дөрес" корымыгызны каян алыйк? Нәрсә жибәрәләр, шуны тутырабыз инде...», - диләр. Әлеге корым шул ук заводларда житештерелсә дә, ул чорда план беренче урында була...

Ләкин уңай мисаллар да күп була. Хирурглар сынган сөякләрне ялгаганда вакытлыча тоташтыру урынына металл таякчыклар куялар. Ләкин врачлар аларны кайчан алырга икәнлеген төгәл белмиләр. Шул вакытта Казан травматология институтына сөяк сөяленең үсү вакытын ЭПР нигезендә билгели торган метод тәкъдим ителә. Бу методны Гарифжанов уйлап таба, ә Казан медиклары аны уңышлы куллана. Шулай ук Гарифжанов hәм аның шәкертләре тарафыннан томография ярдәмендә шешләр диагностикасын тизләтү ысуллары өйрәнелә һәм алар практикада уңышлы кулланыла. 
Бөек галим Н.С. Гарифжанов үзенең 50 яшьлек юбилеена ике ай кала вафат була.

Күчмә һәм лантаноид элементларның парамагнит комплексларын өйрәнү галимгә бөтен дөньяда танылу китерә. Бу тишеренүләр химик физикада яңа юнәлешкә -парамагнит комплекслар төзелешен һәм үзлекләрен аларны аермыйча гына өйрәнүгә - юл ачкан. Ул ясаган ачышка - металл комплексларның гадәти булмаган валентлы халәтләрдә булуына химиклар башта ышанмаганнар, соңыннан ул тулаем танылган.

Н.С. Гарифжановның исемен мәңгеләштеру максатыннан, ул укыган Малмыж урта мәктәбенә аның исеме бирелгән, ә 1971 нче елның 11 нче маенда Казан шәһәр депутатлары советы башкарма комитеты Казанның таулар бистәсендәге бер урамга профессор $\mathrm{H}$. Гарифжанов исемен бирергә карар кылган. Казанның ин матур урамнарының берсе Н.С. Гарифжанов исемен йөртә. Галим турында «Наука жить» дигән документаль фильм төшерелгән.
1970 нче елда, Н.С. Гарифжанов вафатыннан соң, академик Е.К. Завойский инициативасы белән ел саен үткәрелә торган Гарифжанов укулары оештырылды. СССР Фәннәр академиясе әгъза-корреспонденты Б.М. Козырев Н.С. Гарифжанов укуларында болай дигән: «Бу кеше бик сирәк рухи сыйфатларга ия иде. Мәрхәмәтле, кеше хәленә керүчән, йомшак күңелле булуы аның белән аралашкан һәркемгә билгеле. Аның гадилеге искиткеч үзенчәлекле иде. Ижади энтузиазмы барлык укучыларына һәм хезмәттәшләренә күчә иде. Аның да, аларның да эшләре гөрләп бара иде. Әгәр дә кем турындадыр “ул эштә янып бетте” дип әйтергә мөмкин икән, бу аның турында булыр».

\section{Әдәбият}

Мәшһүр татар галимнәре: мәкаләләр, истәлекләр/ [төз.: Р.Ә. Шакиржанов, А.И. Нарбеков, Ф.Р. Шакиржанов]. Казан: Татар. кит. нәшр., 2011. 423 б.: фот. б-н.

Эксперименты от профессора Гарифьянова made in USSR, проверено в США/ БИЗНЕС Online: https://www.business-gazeta.ru/article/468729 